\title{
Honoré de Balzac, La Casa del mistero
}

\section{Marco Stupazzoni}

\section{(2) OpenEdition}

\section{Journals}

\section{Edizione digitale}

URL: https://journals.openedition.org/studifrancesi/3138

DOI: 10.4000/studifrancesi.3138

ISSN: 2421-5856

\section{Editore}

Rosenberg \& Sellier

\section{Edizione cartacea}

Data di pubblicazione: 1 juillet 2013

Paginazione: 470

ISSN: 0039-2944

\section{Notizia bibliografica digitale}

Marco Stupazzoni, «Honoré de Balzac, La Casa del mistero», Studi Francesi [Online], 170 (LVII | II) | 2013, online dal 30 novembre 2015, consultato il 01 février 2023. URL: http://journals.openedition.org/ studifrancesi/3138; DOI: https://doi.org/10.4000/studifrancesi.3138

\section{Questo documento è stato generato automaticamente il 1 février 2023}

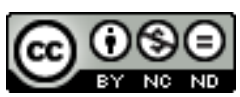

Creative Commons - Attribuzione - Non commerciale - Non opere derivate 4.0 Internazionale - CC BY NC-ND 4.0

https://creativecommons.org/licenses/by-nc-nd/4.0/ 


\title{
Honoré de Balzac, La Casa del mistero
}

\author{
Marco Stupazzoni
}

\section{NOTIZIA}

HONORÉ DE BALZAC, La Casa del mistero, a cura di Beppe BENVENUTO, traduzione di Giovanna TIRA, Milano, Mursia, 2011, «Indizi», pp. 79.

1 Con il titolo di La Casa del mistero, è presentata al pubblico italiano una nuova traduzione de La Grande Bretèche: pubblicato in prima edizione nel febbraio 1837, il racconto sarà poi inserito nell'edizione Furne del 1845 con il sottotitolo: «Fin de Autre Étude de fermme».

2 Questo testo, un vero "gioiellino noir», come lo definisce B. Benvenuto nella sua Postfazione (pp. 73-78; cit. p. 73), ambientato a Vendôme e legato ad uno dei periodi più problematici e dolorosi di Balzac nella stagione del trapasso dall'infanzia all'adolescenza, mette alla prova «il talento affabulatorio di un formidabile narratore, capace, come pochi altri, di utilizzare, con sapienza e mestiere, ogni minimo spunto che la realtà offre alla sua impagabile versalità combinatoria» (pp. 75-76). 